\title{
Riots Expose Bleak Future for Corrections in Massachusetts and Nationwide Charles N. Diorio
}

$\mathrm{O}$ n 9 January 2017, fifty-one prisoners of the Souza-Baranowski Correctional Center destroyed a steel and concrete housing unit. Guards were unable to control the riot for nearly three hours. Glass was shattered, computers were broken, the ceiling was torn down. Prison officials described the events as "gang violence" - it was not. On February 1st, there was an uprising in a maximum-security prison in Smyrna, Delaware. One guard was killed, while other corrections officers and staff held hostage were released. Prison officials forced their way into the cellblock using a backhoe to break through the cinderblock and steel unit. What these two events have in common are the deplorable conditions of confinement that plague correctional facilities nationwide. Prisoners are allowed nothing and, therefore, have nothing to lose.

Winston Churchill remarked in 1910, "The mood and temper of the public in regard to the treatment of crime and criminals is one of the most unfailing tests of the civilisation of any country". ${ }^{2}$ Churchill went on to say that no matter how modern or improved conditions of confinement may appear, "the convict stands deprived over everything a free man calls life". ${ }^{3}$ Today, the conditions in our prisons have changed little, but for the technology.

The Souza-Baranowski Correctional Center (SBCC) is a Massachusetts maximum-security prison built in 1998. At the time, it was constructed with the highest degree of technological integration of any prison in the nation, including a keyless security system and one of the largest closed circuit camera matrix systems in the country. ${ }^{4}$ The facility census population is $1,138^{5}$ and the annual cost per prisoner was is $\$ 54,842$ dollars five years ago. ${ }^{6}$ Yet, for all this costly innovation, prisoners still languish in miserable conditions housed in units where there is little opportunity for recreation, meaningful programs or rehabilitation. Heavy steel doors open and close when guards push a button on a computer screen. Units are locked down easily and often. Like a dystopian nightmare, the opening of the slider informs prisoners of their movement obligation. Forced association, sensory deprivation, crowded conditions and abject misery create a strange distraction, a confusion that feels like a nightmare marked by the surreal.

Here in the Souza-Baranowski Correctional Center, prisoners are being underfed, and bodies grow thin and unhealthy. ${ }^{7}$ Food is served on unsanitary trays and often arrives swimming in dishwater. Drugs flourish, as does 
extortion and violence. Sterile hopelessness fuels a runaway drug culture throughout the prison system. A routine of addiction, trafficking, along with a culture of gambling and idle desperation, mark daily life in these guarded miserable places. Several times every day in SBCC, a disconnected voice announces: "We have an emergency. Freeze all units. We have an emergency. All direct alarm carriers call". This announcement marks a fight, a protest, a disturbance or some other ugliness bringing the facility to a halt.

Prison officials despise scrutiny. When a riot reaches beyond the tall walls and deadly razor-wire, authorities often give the public an easy narrative: gang violence. In the uprising of January $9^{\text {th }}$, SBCC officials informed the public that "a fistfight between two prisoners who are both high-ranking gang members" sparked the melee. ${ }^{8}$ However, the fight and protest was actually the result of guards prohibiting prisoners from showering after gym recreation.

Institutions like Souza-Baranowski are pressure cookers. Fights are a daily occurrence. Prisoners feel abandoned. Food and services are not adequate. Prisoners feel like they are merely bodies allowed to languish as facilities profit off their incarceration. The budget for the Massachusetts prisons was \$569 million dollars for the 2017 fiscal year. ${ }^{9}$ This is a great deal of money for the operation and management of just over 10,000 prisoners. ${ }^{10}$ It is not lost on prisoners that so much money is not being spent on adequately meeting their basic needs. Prisoners feel thrown into hell. As a result, many wrestle with their moral conscience every day. Convicts carry a great deal of emotional baggage. Many lose control because unpacking that baggage is difficult. Facing such circumstances, many lack moral conscience or turn to drugs and these substances fuel bad choices. It is within this context that riots erupt.

Living amongst people convicted of various felonies is a fact of life in every prison worldwide. Sadly, prisons like SBCC have become default dumping grounds for surplus labour and the mentally ill, which only exacerbates mental health issues. ${ }^{11}$ Modern American prisons are technological behemoths with an emphasis on social engineering. Artificial barriers between prisoners and society are erected. Courts, legislators and the public allow prison officials unbridled authority. ${ }^{12}$ Lessons must be learned from events in the James T. Vaughn and Souza-Baranowski correctional facilities. Since the explosion of mass incarceration beginning in the 1980s, these institutions have been practicing a harsh form of social architecture. Bit by bit, essential human rights and hard-fought privileges have been taken away. ${ }^{13}$ 
Rather than elevating education and rehabilitation programs, which give people hope, these expensive institutions have begun a race to the bottom. An effort to modernize and make uniform prisons coast-to-coast has created an artificial and repressive environment where prison officials justify cruel conditions as a mission to safeguard institutional safety and security. Relative deprivation and a fear of losing privileges frustrates prisoners' expectations and protests rage daily. Grievance programs are ineffective; most grievances are entirely ignored. Results are often negative, which are denied by officials. Prisoners are left feeling frustrated and hopeless.

Personal property is treated as garbage by correctional officers. Mail delivery is spotty at best and undelivered at worst. A cruel prisoner code of conduct contributes to the dark miasma that churns out future generations of criminals. Warehousing bodies, along with a total lack of legislation and oversight fuel an emboldened rank-and-file within these prisons to act badly. Each day an alarm is sounded when violence locks down cellblocks. While prison administrators offer the public well-rehearsed narrative, the truth remains: these facilities desperately need reform.

Self-approving institutions, like prisons, inaccurately describe events as riots, rather than rebellions sparked by deplorable conditions. Prisoners across the nation suffer in misery in facilities that have developed into disciplinary detention units. Coming to terms with the truth of these institutions is a Herculean effort - an effort that today more than ever demands planning and a commitment to change by the legislative and executive branches of government.

\section{ENDNOTES}

1 Levenson, Michael (2017) "Prisoners in riot were "getting ready for war", The Boston Globe - January 1.

2 Gilbert, Martin (1991) Churchill: A Life (first American edition), New York: Henry Holt \& Co, p. 214.

3 Ibid. As Home Secretary, "Churchill's prison reform was a real understanding of the nature of imprisonment from the perspective of the prisoner. In his speech of July 10th 1910 he told the House of Commons: "We must not forget that when every material improvement has been effected in prisons, when the proper food to maintain health and strength has been given, when the doctors and chaplains and prison visitors have come and gone, the convict stands deprived over everything that a free man calls life. We must not forget that all these improvements, which are sometimes salves to our consciences, do not change that position"”." 
4 Massachusetts Department of Correction Prison Population Trends 2015: Institution Overview, p. 7.

5 Ibid, p. 1.

6 MA DOC Prison Population Trends (2015) Annual Cost Per Prisoner.

7 Siporin, Steve (2015) “The Kosher Con Game: Who's Keeping Kosher in Prison?", Western Folklore, 74(1): 58-79.

8 Supra note 1.

9 Department of Correction (2017) Historical Budget Levels.

10 Massachusetts Department of Correction. Executive Director of Strategic Planning \& Research. Rhiana Kohl, Ph.D, Director (Executive Summary).

11 Dr. Kenneth Appelbaum, Chief Psychiatrist for the vendor, Massachusetts Correctional Health Services, testified of a "dire need" for a high security residential treatment facility as an alternative to segregation for prisoners with mental illnesses and that the number of mental health clinicians was inadequate. The Department of Corrections maintains it offers "adequate" protection to prisoners with mental illness. Also see Spitzer, Steven (1975) "Toward a Marxian Theory of Deviance", Social Problems, 22(5): 638-651.

12 Procunier v. Martinez 416 U.S. 396, "Where state penal institutions are involved, federal courts have a further reason for defence".

13 "The war on drugs precipitated soaring arrests of drug offenders and increasing racial disproportions among the arrestees" - Human Rights Watch (2000) United States Punishment and Prejudice: Racial Disparities in the War on Drugs, 12(2).

\title{
ABOUT THE AUTHOR
}

Charles N. Diorio is currently a prisoner living in the Souza-Baranowski Correctional Center. He can be reached at the addresses listed below:

\author{
Charles N. Diorio W103769 \\ Souza-Baranowski C.C. \\ P.O. Box 8000 \\ Shirley, Massachusetts 01464 \\ USA \\ Attorney James J. Gavigan, Esq. \\ 80 Billings Road \\ N. Quincy, Massachusetts \\ USA
}

